\title{
What next for MDGs?
}

$\mathrm{F}$ ew indicators have been as lauded, or as reviled, as the Millennium Development Goals (MDGs). Almost from the moment the eight international objectives, complete with 21 targets, were established in the year 2000 following the United Nations Millennium Summit, they have engendered impassioned opinion.

Supporters assert that the MDGs which have been signed by all 193 UN member states and about two dozen international bodies, such as the World Health Organization (WHO), the World Bank and the International Monetary Fund - have improved social and economic conditions worldwide. The MDGs, boosters say, are a blueprint for a healthier world, have helped to reduce poverty by $50 \%$, have increased school enrolments in Asia and Africa, and have bolstered global efforts to combat HIV/AIDS and other infectious diseases.
Critics have countered that the MDGs don't necessarily indicate much that needs indicating, are methodologically flawed, lack anything vaguely resembling scientific rigour, have done nothing to reduce global inequities and should be replaced with goals that pack a punch. As configured, they're little more than "a failed catalogue of global health," says Stephen Lewis, former UN special envoy for HIV/AIDS in Africa.

But with the 2015 deadline for the eight goals - eradicate extreme poverty and hunger; achieve universal primary education; promote gender equality and empower women; reduce child mortality rates; improve maternal health; combat HIV/AIDS, malaria, and other diseases; ensure environmental sustainability; [and] develop a global partnership for development (www.un.org/millenniumgoals/bkgd .shtml) - looming, the question becomes: What next?

In hopes of resolving the question, the UN agreed in 2010 to launch a global exercise to renew and reshape the MDGs. Secretary-General Ban Ki-moon subsequently appointed 26 civil society, private sector and government leaders to a "high-level panel" to craft a global development agenda beyond 2015. In support of that, the $\mathrm{UN}$ is encouraging submissions and consultations, so international bodies and civil society organizations are scrambling to develop and make the case for other indicators.

Already, WHO is urging the inclusion of universal health coverage as a new indicator (www.who.int/topics /millennium_development_goals/post 2015/WHOdiscussionpaper_October 2012.pdf)

Consultations are now underway in

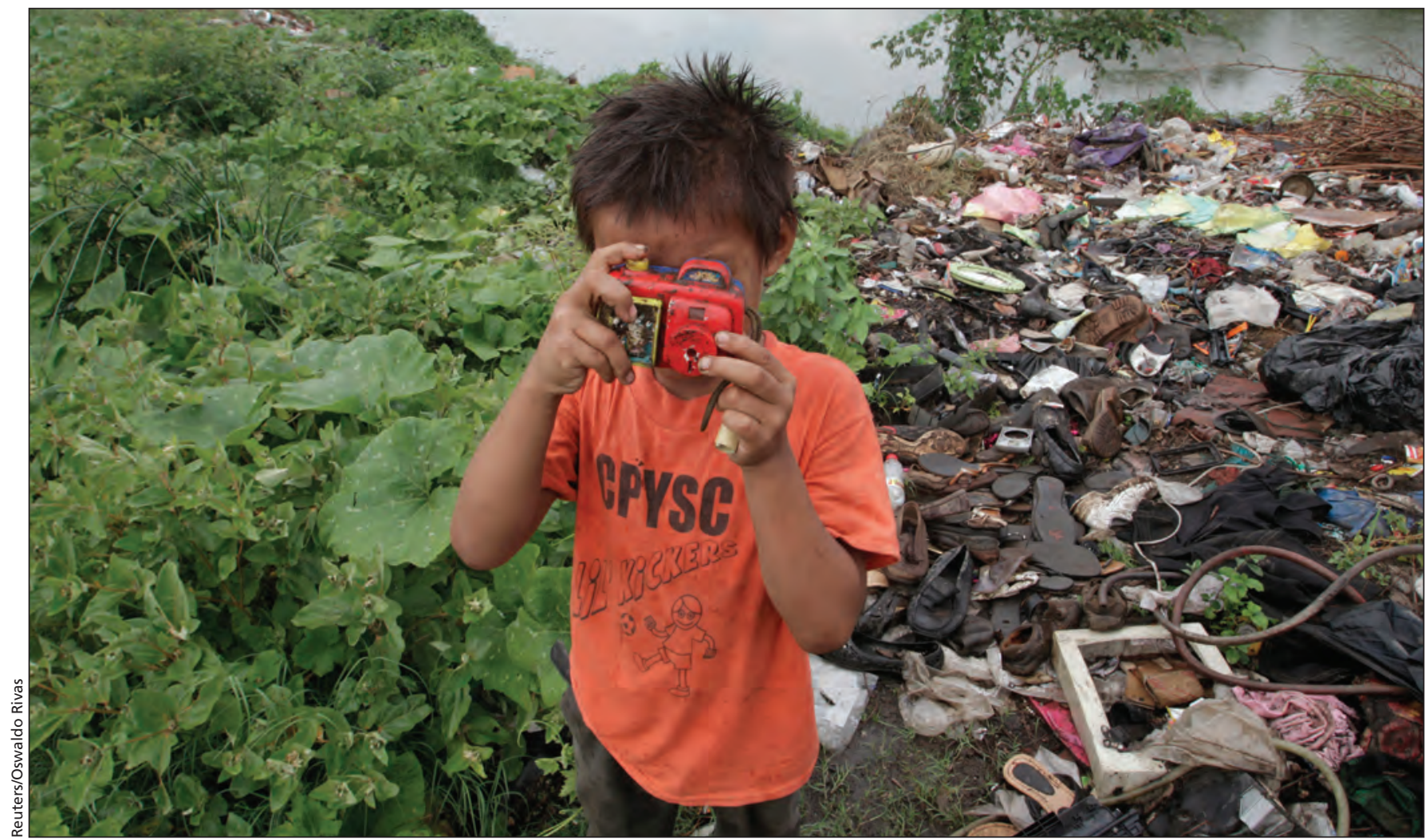

A child poses with a toy camera while collecting materials from a La Chureca, Managua, garbage dump. The Millennium Development Goals have helped to reduce global poverty by $50 \%$, supporters argue. 
50 countries to inform the high-level panel, which will be chaired by the governments of Liberia, Indonesia, and the United Kingdom, and which will make recommendations to the UN by June, 2013. Proposals for new MDGs are expected to be addressed at a summit in September 2013.

Delegates to a gathering of international MDG experts organized at Ryerson University in Toronto, Ontario, in late October made the case for a substantial broadening of the MDGs.

They need to be dramatically expanded to tackle issues such as international trade, intellectual property regimes, labour and employment problems, and migration, argued Thomas Pogge, director of the Global Justice Program, professor of philosophy and international affairs at Yale University in New Haven, Connecticut.

Pogge, chair of the Academics Stand Against Poverty, a group of universitybased MDG analysts that organized the Ryerson gathering in collaboration with Beyond 2015, a coalition of 380 nongovernmental organizations, also urged the adoption of more rigorous statistical tracking of targets to prevent fudging by agencies seeking to validate the current set of MDGs, "in part, because a ridiculously low poverty line is used to measure progress, which delivers a better looking trend."

The current MDGs are neutered by a lack of legal and administrative pur- chase, argued Varun Gauri, senior economist with the Development Research Group of the World Bank in Washington, DC. "We should think about MDGs that nudge," he said. "It's simply not the case that most countries put global poverty high on their priority lists."

Concurring with that proposition was Dr. James Orbinski, director of the Africa Initiative with the Centre for International Governance Innovation and chair of global health at the Balsillie School of International Affairs in Waterloo, Ontario, who argued that the MDGs need to be ratcheted-up. While the current MDGs have helped to expand access to antiretroviral therapies for the treatment of HIV/AIDS in Africa, they represent "lowest common denominators" that yield half measures, he said.

Orbinski also argued that climate change is unleashing catastrophic health and economic impacts that "require practical action" and should be central within any new MDGs.

Others argued that an entirely new approach must be taken. The current MDGs are "hideously biased against countries that started with bad numbers," and are essentially a "set up for failure," argued Sakiko Fukuda-Parr, professor of international affairs at The New School, a university in New York City, and former director of human development reports for the UN Development Programme.
The MDGs have "dumbed down the agenda. The goals effectively worked as a cover for extreme free market policies," she said. Development planning "should simply not be done this way. I am now persuaded these goals are dangerous."

Gauri urged that the new MDGs include specific national and regional targets, not just global targets, as has been recommended in recent policy papers issued by the UN system Task Team (www.un.org/millenniumgoals /pdf/Post_2015_UNTTreport.pdf) and the Canadian Centre for International Governance Innovation (www.cigi online.org/publications/2012/10/post -2015-development-agenda-goals-targets -and-indicators).

While conference organizer Mitu Sengupta, associate professor of politics and public administration at Ryerson, argued that civil society groups and academics now have an enormous opportunity to influence the reshaping of the MDGs, Gauri cautioned that expectations for an expanded set of goals and greater accountability in "MDGs 2.0" may be overly optimistic. The renewal of the MDGs cannot be assumed and major multilateral organizations such as the World Bank have not yet firmly committed to their renewal, he noted. - Paul Christopher Webster, Toronto, Ont.

CMAJ 2012. DOI:10.1503/cmaj.109-4332 